\title{
THE EFFECT OF PHYTOBIOTICS SUPPLEMENTATION AND MAGNETIZED DRINKING WATER ON PRODUCTION PERFORMANCE AND EGG QUALITY OF LAYING HENS
}

\author{
Filoza Marwi ${ }^{1)}$, Osfar Sjofjan²), Adharul Mutaqin ${ }^{3)}$, Muhammad Halim Natsir*2) \\ 1) Postgraduate Student, Faculty of Animal Science, Universitas Brawijaya, Jl. Veteran Malang, 65145, \\ Indonesia \\ ${ }^{2)}$ Lecturer, Department of Animal Nutrition and Feed Science, Faculty of Animal Science, Universitas \\ Brawijaya, Jl. Veteran Malang, 65145, Indonesia \\ ${ }^{3)}$ Lecturer, Department of Electrical Engineering, Faculty of Engineering, Universitas Brawijaya, Jl. Veteran \\ Malang, 65145, Indonesia \\ *Corresponding Email: emhanatsir@ub.ac.id
}

Submitted 27 January 2021; Accepted 30 March 2021

\begin{abstract}
The experiment was conducted to evaluate the production performance and egg quality of laying hens supplemented with phytobiotics and magnetized drinking water. This experiment used 2700 gauss level in Magnetized Drinking Water (MDW). The phytobiotics had two form: the non-encapsulated phytobiotics (PTO) and encapsulated phytobiotics (EPTO). There were untreated water (control) and the treated water (MDW, PTO, PTO+MDW, EPTO, EPTO+MDW). The treatments were presented by $0.6 \%$ for each treatment. The result showed highly significant $(p<0.01)$ improvement on feed conversion ratio (FCR) but no significant effect on other production performance variables including feed intake, hen day production (HDP), egg mass, and income over feed cost (IOFC). The results indicated a highly significant improvement $(p<0.01)$ on egg weight and yolk cholesterol. There were no significant effects on shape index (SI), shell weight, shell thickness, Haugh unit (HU), albumen height, yolk weight, yolk index (YI), and yolk color of egg quality variables. It was concluded that the encapsulated form (EPTO and EPTO+MDW) had the best improvement on FCR and yolk cholesterol, on another hand the non-encapsulated form (PTO and PTO+MDW) increased the egg weight of laying hens.
\end{abstract}

Keywords: Drinking water quality; egg; magnet; yolk cholesterol. 


\section{INTRODUCTION}

The use of Antibiotic Growth Promoters (AGPs) has been prohibited in the livestock production. Using natural growth promoters (NGPs) is one of the efforts to solve this problem. Phytobiotic is NGPs that are derived from plants. Phytobiotic has some functions such as growth-promoting effect, antimicrobial activity, anti-inflammation activity and improve the performance and egg quality of the laying hens (Ayeni et al., 2020; Gheisar and Kim, 2018; Hazrati et al., 2019). Phytobiotic optimizes the gut system and improves the performance production and egg quality of laying hens by utilizing the bioactive compounds which are contained in the plant.

There are many herb plants used for phytobiotic. Ginger and turmeric are a great combination that was studied in many previous pieces of research. Ginger used at a specific level increases egg weight, improves egg quality, reduces the percentage of yolk cholesterol content, and had a positive effect on immunomodulation, antioxidant and growth hormone (El-Hack et al., 2020; Kafi et al., 2017; Wen et al., 2019). The use of turmeric as phytobiotic has benefits on parameters of production performance, egg quality, gut morphology, immunological profile, and economic efficiency (Azouz 2020; Kinati et al., 2021; Kosti et al., 2020; Mousa et al., 2019; Rahman et al., 2021).

The powder phytobiotic in feed had low homogeneity. Sinurat et al. (2020) reported that diet supplemented by powder phytobiotics had lower improvement than liquid phytobiotics on production performance (body weight, feed intake, and feed conversion ratio). The higher feed intake in powder phytobiotics increased the feed cost. The circumstance will decrease the profit. On the other hand, the use of liquid phytobiotic in drinking water has low durability which is effectively just held by two to four hours in drinking water. The encapsulation technology will protect phytobiotic and increase durability. The encapsulation technology protects bioactive in feed by adding encapsulant as a coating so that the bioactive protected from the damages (Lee et al., 2020; Natsir et al., 2013).

The use of phytobiotic is affected by the quality of drinking water. The magnetized drinking water in 1850, 3000, 6500 , and 14500 Gs levels increases water quality also improves growth hormone, production performance, egg quality, and immune function of laying hens (Abobatta, 2019; Darsi et al., 2017; El-Sabrout and Hanafy, 2017; El-Sabry et al., 2020; Mitre, 2018). The water generally contains $\mathrm{HCO}_{3}-$, $\mathrm{Mg}^{2+}, \mathrm{Na}^{+}, \mathrm{Cl}^{-}, \mathrm{CO}_{3}{ }^{2-}$ and $\mathrm{Ca}^{2+}$ (El-Sabrout and Hanafy, 2017). The $\mathrm{CO}_{3}{ }^{2-}$ and $\mathrm{Ca}^{2+}$ formed the calcium carbonate ions $\left(\mathrm{CaCO}_{3}\right)$ which create the suspended solids and increase the growth of bacteria in drinking water. Gabrielli et al. (2001) stated that using magnetized water will release $\mathrm{Ca}^{2+}$ in water.

The $\mathrm{Ca}^{2+}$ is used as an antibacterial compound to decrease population of the pathogenic bacteria in drinking water. Using magnetized drinking water increases body weight and feed conversion ratio (FCR) in poultry also effects for improving heart functions, performance production, egg quality, reproduction hormones (estrogen and progesterone), antioxidants in the blood, also all biochemical and physiological
*Corresponding author:

Muhammad Halim Natsir

Email: emhanatsir@ub.ac.id

Lecturer, Department of Animal Nutrition and Feed

Science, Faculty of Animal Science, Universitas

Brawijaya, J1. Veteran Malang, 65145, Indonesia
How to cite:

Marwi, F., Natsir, M. H., Sjofjan, O., \& Mutaqin, A. (2021). The Effect of Phytobiotics Supplementation and Magnetized Drinking Water on Production Performance and Egg Quality of Laying Hens. Jurnal Ilmu dan Teknologi Hasil Ternak (JITEK), 16 (2), 95-104 
properties (Al-Hilali, 2018; El-Hanoun et al., 2017). This study aims to evaluate the effect of phytobiotics supplementation and magnetized drinking water on production performance and egg quality of laying hens.

\section{MATERIALS AND METHODS}

\section{Materials}

This study used the phytobiotic containing Zingiber officinale var. amarum and Curcuma longa Linn. The 2700 gauss level of magnet was counted by gaussmeter in Electro Engineering Laboratory of the Faculty of Engineering Universitas Brawijaya. The encapsulated phytobiotic used 2 coating process. Chitosan was used for the first coating process and the second coating process used a combination of whey protein and Arabic gum as encapsulants. The encapsulation was conducted in the Animal Feed Industry Laboratory of the Faculty of Animal Science Universitas Brawijaya. The self-mix feed used in this research was analyzed in the Animal Nutrition and Feed Laboratory of the Faculty of Animal Science Universitas Brawijaya (Table 1).

The experiment used 288 57-week-old ISA Brown laying hens that were raised in a single battery cage $(30 \mathrm{~cm} \times 35 \mathrm{~cm} \times 40 \mathrm{~cm})$. The egg weight was counted by digital scales precision 0.01 . The micrometer screw, digital calipers, and tripod micrometer were used for counting the other egg quality variables. The yolk color was counted by the yolk color fan. The yolk cholesterol was analyzed at the Animal Science Laboratory of Universitas Padjajaran.

Table 1. Ingredients and Nutrient Contents of Feed

\begin{tabular}{lccc}
\hline \multicolumn{1}{c}{ Ingredients } & Value $(\%)$ & Nutrient Content & Value (\%) \\
\hline Corn & 52.7 & Dry Matter & 90.28 \\
Rice brain & 13.95 & Metabolism Energy & 2959 \\
Soybean meal & 24.5 & $(\mathrm{kcal} / \mathrm{Kg})$ & 19.44 \\
Meat bone meal & 4.7 & Crude Protein & 2.95 \\
Grit & 3.1 & Crude Fiber & 4.93 \\
Lysine & 0.1 & Crude Fat & 7.99 \\
Methionine & 0.15 & Ash & \\
Premix a & 0.2 & & \\
Salt & 0.2 & & \\
Monocalcium Phosphate & 0.4 & & \\
Total & 100 & & \\
\hline
\end{tabular}

a) Premix from PT. MITRAVET (Composition/1 kg: vitamin $\mathrm{A}=2.000 .000 \mathrm{IU}$, vitamin $\mathrm{D} 3=400.000 \mathrm{IU}$, vitamin $\mathrm{E}=3.000 \mathrm{mg}$, vitamin $\mathrm{K}=400 \mathrm{mg}$, vitamin $\mathrm{B} 12=4 \mathrm{mcg}$, thiamin $\mathrm{HCI} / \mathrm{B} 1=400 \mathrm{mg}$, riboflavin $\mathrm{HCI} / \mathrm{B} 2=1.200 \mathrm{mg}$, pyridoxin $\mathrm{HCI} / \mathrm{B} 6=800$ $\mathrm{mg}, \mathrm{Ca}$-d-pantothenate $=2.160 \mathrm{mg}$, niacinamide $=8.000 \mathrm{mg}$, folic acid $=200 \mathrm{mg}$, biotin $=4 \mathrm{mg}$, L-Carnitine $=10.000 \mathrm{mg}$, copper sulphate $=4.000 \mathrm{mg}$, cobalt sulphate $=300 \mathrm{mg}$, ferro sulphate $=10.000 \mathrm{mg}, \mathrm{Mn}$ oxide $=20.000 \mathrm{mg}$, sodium selenite $=150$ $\mathrm{mg}$, carrier $\mathrm{ad}=1.000 \mathrm{mg}$.

\section{Methods}

The method used was in vivo experiment with a completely randomized design. This study applied the magnetized drinking water (MDW) and two forms of phytobiotics (non-encapsulated phytobiotics (PTO) and encapsulated phytobiotics (EPTO)). The experiments consisted of the untreated water (control) and the treated water with five formulas (MDW, PTO, PTO+MDW, EPTO, and EPTO+MDW). There were six groups divided randomly with four replicates that containing twelve laying hens for each replicate. PTO and EPTO were presented by $0.6 \%$ of drinking water with ad libitum method for six weeks 
(forty-two days). The feed was presented by the restricted feeding method once a day with $120 \mathrm{~g} / \mathrm{head} /$ day. Variables of production performance were feed intake, hen day production (HDP), egg mass, feed conversion ratio (FCR), and income over feed cost (IOFC). The feed intake was counted once a week by calculating the leftover feed. Collected eggs were counted twice a day for HDP. Egg mass was a result from HDP multiplied by egg weight. FCR was calculated by feed intake divided egg mass. Calculating IOFC used the following formula.

$$
\begin{gathered}
\text { IOFC }=(\text { egg mass } \times \text { egg cost })-(\text { feed intake } \times \text { feed cost }) \\
S I=(\text { egg width }(\mathrm{mm}) \div \text { egg length }(\mathrm{mm})) \times 100 \\
H U=100 \log _{10}\left(\text { albumin height }(\mathrm{mm})-1.7 \times \text { egg weight }(\mathrm{g})^{0.37}+7.6\right) \\
Y I=(\text { yolk height }(\mathrm{mm}) \div \text { yolk diameter }(\mathrm{mm})) \times 100
\end{gathered}
$$

Egg quality variables were egg weight, shape index (SI), shell weight, shell thickness, haugh unit (HU), albumen height, yolk weight, yolk index (YI), yolk color, and yolk cholesterol. The formulas of SI, HU, and YI were presented above (Alasahan and Copur, 2016; Roberts, 2004). Digital caliper was used for counting egg width and egg length. Egg weight was calculated on daily egg recording. Shell weight was counted by scale with precision 0.001 . Shell thickness used micrometer screw. Albumen height was calculated by micrometer tripod. Yolk color was known by using yolk color fan with eight color level. The yolk cholesterol used kits with CHOD-PAP (enzymatic photometric test) method (Diasys Diagnostic Systems GmbH 2005).

\section{Statistical Analysis}

The data obtained was analyzed by analysis of variance (ANOVA) followed with Duncan's multiple tests on significant results. The statistical analysis used the SPSS software (version 26) from IBM, USA.

\section{RESULT AND DISCUSSION}

\section{The Effect of Phytobiotics Supplementation and Magnetized Drinking Water on Production Performance of Laying Hens}

This study had evaluated the production performance of phytobiotics supplementation ((non-encapsulated phytobiotics (PTO) and encapsulated phytobiotics (EPTO)) and magnetized drinking water (MDW) on feed intake, hen day production (HDP), egg mass, feed conversion ratio (FCR), and income over feed cost (IOFC) (Table 2).

The result showed highly significant effect $(p<0.01)$ on FCR and there was no effect on other variables of performance production. The lowest result was shown by PTO (109.13 g/head/day). HDP results showed that EPTO+MDW had the highest result $(90.87 \%)$. The lowest result of HDP was PTO (82.92\%). Generally, using MDW improved HDP than treatments without MDW. The highest result of egg mass in this research was shown by EPTO+MDW (57.12 $\mathrm{g} / \mathrm{head} /$ day). Control $(52.33 \mathrm{~g} / \mathrm{head} /$ day) had the lowest result in this variable. EPTO (1.94) had the best result shown on FCR. IOFC showed that EPTO (464.45 IDR/head/day) had the best result while the lowest result was shown in control (359.36 IDR/head/day).

The use of MDW improved the water quality. The better water quality increased the absorption nutrient of feed. The results of present study are in line with previous (El-Sabrout and El-Hanoun, 2019; Gholizadeh et al., 2008). The improvement of feed efficiency is affected by better nutrient absorption in the gastrointestinal by phytobiotic. Phytobiotic had been proven improving gastrointestinal function and nutrient digestibility, gut microflora, and immune function (Grashorn, 2010; Mousa et al., 2019). Encapsulation technology used chitosan, whey protein, and Arabic gum as 
encapsulants. The encapsulant protects phytobiotic so that it can optimize the digestion and absoprtion. Arabic gum and whey protein as encapsulants affected digestibility and metabolism in the gut system. This circumstance improves poultry immunity, egg production and egg quality (Chen and Chen, 2004; Pineda-Quiroga et al., 2017).

There was no significant effect on egg mass, wherease the use of phytobiotic treatments numerically increased egg mass of laying hens. Sunder et al. (2013) reported that addition phytobiotic increases egg weight. The research had a similar effect to treatment by phytobiotic. The lower the FCR is, the better the performance production of laying hens. The EPTO that contains encapsulated phytobiotic without magnetized drinking water. The result in this study agrees with El-Katcha et al. (2017) that showed the uses of a magnetic system in drinking water of poultry improved the feed conversion. Turmeric content of phytobiotic affected better performance on the feed conversion ratio variable (Kinati et al., 2021). Improving FCR would decrease feed intake and increase egg production. EPTO had higher result than others on IOFC even though there is no statistically effect. The encapsulated phytobiotic optimized the absorption nutrient in laying hens.

On other hand, the laying hens will decrease their feed intake because phytobiotics optimize the absorption of nutrients and energy and affect the faster fulfill in the gut of laying hens. This circumstance was affected by the increasing non-pathogenic bacteria population in the digestibility of laying hens. Presented the encapsulated feed increased the population of non-pathogenic bacteria compared to non-encapsulated feed (Natsir et al., 2013; Natsir et al., 2010).

Table 2. The effect of phytobiotics supplementation and magnetized drinking water on production performance of laying hens

\begin{tabular}{|c|c|c|c|c|c|c|c|c|}
\hline & Control & MDW & PTO & PTO+MDW & EPTO & EPTO+MDW & SEM & $p$-value \\
\hline $\begin{array}{l}\text { Feed Intake } \\
\text { (g/head/day) }\end{array}$ & 115.64 & 111.01 & 109.13 & 113.11 & 109.63 & 113.60 & 0.75 & 0.068 \\
\hline $\begin{array}{l}\text { Hen Day Production } \\
(\%)\end{array}$ & 85.61 & 87.50 & 82.92 & 87.23 & 88.81 & 90.87 & 0.91 & 0.177 \\
\hline $\begin{array}{l}\text { Egg Mass } \\
\text { (g/head/day) }\end{array}$ & 52.33 & 53.85 & 53.12 & 55.92 & 56.54 & 57.12 & 0.61 & 0.104 \\
\hline $\begin{array}{l}\text { Feed Conversion } \\
\text { Ratio (head) }\end{array}$ & $2.25^{\mathrm{b}}$ & $2.04^{\mathrm{a}}$ & $2.06^{\mathrm{a}}$ & $2.03^{\mathrm{a}}$ & $1.94^{\mathrm{a}}$ & $1.99^{\mathrm{a}}$ & 0.02 & $<0.01$ \\
\hline $\begin{array}{l}\text { Income Over Feed } \\
\text { Cost (IDR/head/dav) }\end{array}$ & 359.36 & 413.42 & 406.11 & 437.28 & 464.45 & 453.24 & 11.83 & 0.104 \\
\hline
\end{tabular}

MDW : Magnetized Drinking Water, PTO: Phytobiotics, EPTO: Encapsulated Phytobiotics, SEM : Standard Error of Means.

${ }^{a-b}$ Different letter indicates highly significant differences between the means $(p<0.01)$.

\section{The Effect of Phytobiotics Supplementation and Magnetized Drinking Water on Egg Quality of Laying Hens}

This study had evaluated the egg quality of phytobiotics supplementation ((non-encapsulated phytobiotics (PTO) and encapsulated phytobiotics (EPTO)) and magnetized drinking water (MDW) on egg weight, shape index (SI), shell weight, shell thickness, Haugh unit (HU), albumen height, yolk weight, yolk index (YI), yolk color, and yolk cholesterol. Table 3 showed the egg quality of phytobiotics supplementation and magnetized drinking water in the laying hens.

The result showed a highly significant effect $(p<0.01)$ on egg weight and yolk cholesterol of egg quality variables. There was no significant effect on other variables of egg quality. PTO $(64.07 \mathrm{~g})$ and PTO+MDW (64.12 g) are the highest result on egg weight. Phytobiotic in this research contains ginger (Zingiber officinale var. 
amarum) and turmeric (Curcuma longa Linn). Using phytobiotic (ginger) on the feed will increase the average egg weight of laying hens (Zhao et al., 2011; Wen et al., 2019).

Ginger has been demonstrated to have various bioactive such as antioxidant and antimicrobial (Zhang et al., 2009; Dedov et al., 2002; Kafi et al., 2017). These favorable effects have contributed to the increase in egg weight of laying hens. The use of turmeric has increased the egg weight of laying hens (Gumus et al., 2018). The additional MDW on the treatments generally decreases SI, shell weight and shell thickness compared to treatments without MDW. SI is classified into 3 groups that are round egg ( $\mathrm{SI}>76)$, standard egg ( $\mathrm{SI}=72$ 76), and sharp egg (SI < 72) (Duman et al., 2016). Roberts (2004) reported that the eggshell of eggs contains up to $3 \mathrm{~g}$ of calcium.

Table 3. The effect of phytobiotics supplementation and magnetized drinking water on egg quality of laying hens

\begin{tabular}{|c|c|c|c|c|c|c|c|c|}
\hline & Control & MDW & PTO & PTO+MDW & EPTO & EPTO+MDW & SEM & p-value \\
\hline Egg Weight (g) & $61.13^{\mathrm{a}}$ & $61.57^{\mathrm{a}}$ & $64.07^{\mathrm{c}}$ & $64.12^{c}$ & $63.67^{\mathrm{bc}}$ & $62.84^{\mathrm{b}}$ & 0.26 & $<0.01$ \\
\hline Shape Index & 76.01 & 75.46 & 78.23 & 77.37 & 77.66 & 78.23 & 0.34 & 0.060 \\
\hline Shell Weight (g) & 7.60 & 7.24 & 7.58 & 7.58 & 7.38 & 7.63 & 0.07 & 0.500 \\
\hline $\begin{array}{l}\text { Shell Thickness } \\
(\mathrm{mm})\end{array}$ & 0.58 & 0.56 & 0.57 & 0.59 & 0.55 & 0.57 & 0.00 & 0.179 \\
\hline Haugh Unit & 73.98 & 76.74 & 84.00 & 79.47 & 78.54 & 78.86 & 1.04 & 0.117 \\
\hline $\begin{array}{l}\text { Albumin Height } \\
(\mathrm{mm})\end{array}$ & 5.85 & 6.37 & 7.47 & 6.75 & 6.56 & 6.53 & 0.16 & 0.072 \\
\hline Yolk Weight & 16.38 & 16.75 & 17.50 & 16.75 & 17.92 & 17.00 & 0.16 & 0.037 \\
\hline Yolk Index & 41.31 & 43.16 & 43.14 & 43.10 & 42.79 & 42.61 & 0.22 & 0.118 \\
\hline Yolk Color & 8.06 & 7.62 & 7.67 & 7.83 & 7.29 & 7.88 & 0.11 & 0.515 \\
\hline $\begin{array}{l}\text { Yolk Cholesterol } \\
(\mathrm{mg} / 100 \mathrm{~g})\end{array}$ & $225.34^{\mathrm{b}}$ & $225.39^{b}$ & $224.75^{b}$ & $225.28^{b}$ & $218.10^{\mathrm{a}}$ & $218.12^{b}$ & 0.73 & $<0.01$ \\
\hline
\end{tabular}

MDW : Magnetized Drinking Water, PTO: Phytobiotics, EPTO: Encapsulated Phytobiotics, SEM : Standard Error of Means. ${ }^{\mathrm{a}-\mathrm{c}}$ Different letter indicates highly significant differences between the means $(p<0.01)$.

These indicate that using MDW decrease the calcium for laying hens. The magnetized water reduces $\mathrm{Ca}$ in drinking water required for eggs. It agrees with previous research reported that observation on $\mathrm{Ca}^{2+}$ concentration in water by magnetization showed a reduction in the concentration of $\mathrm{Ca}$ and $\mathrm{CaCO}_{3}$ in water (Gabrielli et al., 2001; Jiang et al., 2013). Using MDW and phytobiotics generally improved the HU and albumen height on the egg of laying hens. EPTO is the highest result on HU and albumen height variables. The encapsulation technology helps to protect the phytobiotic from the damages on the way to the gut system (Natsir et $a l ., 2013)$. This circumstance will optimize the bioactive contained in phytobiotic in the gut system. Phytobiotics contain turmeric which stimulates the growth of tubular gland cells and epithelial cells in magnum to secrete and synthesize albumen, and increasing the albumen weight (Kinati et al., 2021; Saraswati et al., 2013). Adding MDW and phytobiotics in general increase the yolk weight and YI but affect the decreasing yolk color compared to control treatment.

These similar to previous research which reported that the addition of phytobiotic (ginger) enhanced the YI of laying hens (Incharoen and Yamauchi, 2009; Mousa et al., 2019). Adding 0.5\% phytobiotic (ginger root) has increased the yolk weight in the egg of laying hens (Akbarian et al., 2011). The yolk color highly depends on carotenoid which is the source of red and yellow (xanthophylls) pigments (Englmaierova et al., 2014). Yildirim et al. (2013) reported that xanthophyll is attached to fat-soluble 
pigments in the feed. There is no effect on yolk color in this research may be indicated by the same feed to all treatments. It disagrees to other studies which reported that the addition of phytobiotic (turmeric) increases the results of yolk colors (Kinati et al., 2021; Riasi et al., 2012).

This difference may be affected by the level of percentage the use of phytobiotic, the high results on that research are indicated by more than $\geq 1 \%$ level of used phytobiotic. The best results on yolk cholesterol are EPTO $(218.10 \mathrm{mg} / 100 \mathrm{~g})$ and EPTO+MDW (218.12 mg/100g). The encapsulation technology optimizes the absorption of phytobiotic in the gut system by protecting the phytobiotic from the damages with using encapsulants. The result indicated that EPTO has had better durability and effectivity than PTO. This circumstance pushed the phytobiotic on the nutrient absorption process optimally. It agrees with previous research which reported that the addition of phytobiotic (ginger) effectively decreases the yolk cholesterol in the egg of laying hens (Akbarian et al., 2011; Gurbuz and Salih, 2017; Wen et al., 2019).

\section{CONCLUSION}

This study suggests that the inclusion of phytobiotics supplementation and magnetized drinking water showed better feed conversion ratio, egg weight, and yolk cholesterol. Two types of encapsulated phytobiotics (EPTO and EPTO+MDW) were the best treatment on FCR and yolk cholesterol of laying hens. Phytobiotics treatments (PTO and PTO+MDW) had the highest result on egg weight of laying hens.

\section{ACKNOWLEDGMENT}

The authors acknowledge the financial support from the National Research and Innovation Agency of Indonesia through The Higher Education Excellence Research program.

\section{REFERENCES}

Abobatta, W. F. (2019). Overview of role of magnetizing treated water in agricultural sector development. $A d v$ Agri Tech Plant Sciences, 2 (1), 180023.

Akbarian, A., Golian, A., Ahmadi, A. S., \& Moravej, H. (2011) Effects of ginger root (Zingiber officinale) on egg yolk cholesterol, antioxidant status and performance of laying hens. Journal of Applied Animal Research, 39 (1), 19-21. https://doi.org/10.1080/097121 19.2011.558612

Alasahan, S., \& Copur, A. G. (2016). Hatching characteristics and growth performance of eggs with different egg shapes. Brazilian Journal of Poultry Science, 18 (1), 1-8. https://doi.org/10 .1590/1516-635X1801001-008

Al-Hilali, A. H. (2018). Effect of magnetically treated water on physiological and biochemical blood parameters of Japanese quail. International Journal of Poultry Science, 17, 78-84. https://dx.doi.org/ 10.3923/ijps.2018.78.84

Ayeni, A.O., Oladedun, A.E., \& Agbede. J.O. (2020). Performance and egg qualities of old-laying hens fed with diets containing selected phytogenic feed additives. Journal of Food, Nutrition and Agriculture, 3, 19-25. http://dx.doi.org/10.21839/jfna.2020. v3.330

Azouz, H. M. (2020). Effects of dietary turmeric and fenugreek powder supplementation on productive performance of local laying hens. egypt. Poult. Sci., 40 (1), 243-258. https://dx.doi.org/10.21608/epsj.2020 .81028

Chen, Y. C., \& Chen, T. C. (2004). Mineral utilization in layers as influenced by dietary oligofructose and inulin. Int. J. Poult. Sci., 3 (7), 442-445. https:// dx.doi.org/10.3923/ijps.2004.442.445

Darsi, E., Kermanshahi, H., Moghaddam, H. Nassiri, Golian, A., \& Gholizadeh, 
M. (2017). Effects of magnetized water on In - Vitro calcium carbonate solubility and eggshell breaking strength. J. Agr. Sci. Tech., 19, 14951505. http://hdl.handle.net/12345678 $9 / 3553$

Dedov, V. N., Tran, V. H., Duke, C. C., Connor, M., Christie, M. J., Mandadi, S., \& Roufogalis, B. D. (2002). Gingerols, a novel class of vanilloid receptor (VR1) agonists. British Journal of Pharmacology, 137, 793798. https://doi.org/10.1038/sj.bjp.07 04925

Duman, M., Şekeroğlu, A., Yıldırım, A., Eleroğlu, H., \& Camc1, Ö. (2016). Relation between egg shape index and egg quality characteristics. Europ. Poult. Sci., 80, 1-9. http://dx.doi.org/ 10.1399/eps.2016.117

El-Hack, M. E. A., Alagawany, M., Shaheen, H., Samak, D., Othman, S. I., Allam, A. A., Taha, A. E., Khafaga, A. F., Arif, M., Osman, A., El Sheikh, A. I., Elnesr, S. S., \& Sitohy, M. (2020). Ginger and its derivatives as promising alternatives to antibiotics in poultry feed. Animals, 10 (3), 452. https://doi.org/10.3390/ani10030452

El-Hanoun, A. M., Attia, Y. A., Al-Harthi, M. A., Habiba, H. I., \& de Oliveira, M. C. (2017). Magnetized drinking water improves productivity and blood parameters in geese. Revista Colombiana de Ciencias Pecuarias, 30 (3), 209-218. http://dx.doi.org/ 10.17533/udea.rccp.v30n3a04

El-Katcha, M., Soltan, M., El-Naggar, K., \& Farfour, H. (2017). Effect of magnetic water treatment and some additives on growth performance, some blood biochemical parameters and intestinal health of growing pekin ducklings. Alexandria Journal of Veterinary Sciences, 53, 143-156. http://dx.doi. org/10.5455/ajvs.249419

El-Sabrout, K., \& El-Hanoun, A. (2019). Does magnetised drinking water influence poultry's health and production. World's Poultry Science
Journal, 75 (3), 411-416. https://doi. org/10.1017/S0043933919000266

El-Sabrout, K., \& Hanafy, M. (2017). Effect of magnetized water on productive traits of laying chickens. The Professional Animal Scientist, 33 (6), 739-742. https://doi.org/10.15232/pas .2017-01656

El-Sabry, M. I., Abdelfattah, M. H., Abdellatif, H. A., Aggrey, S. E., \& Elnesr, S. S. (2020). Physicochemical properties of magnetic water and its effect on egg production traits in hens at late laying period. The Journal of Animal and Plant Sciences, 31 (1), 317-321. https://doi.org/10.36899/JA PS.2021.1.0219

Englmaierova, M., Bubancova, I., \& Skřivan, M. (2014). Carotenoids and egg quality. Acta fytotechn. zootechn., 17 (2), 55-57. https://doi.org/10. 15414/afz.2014.17.02.55-57

Gabrielli, C., Jaouhari, R., Maurin, G., \& Keddam, M. (2001). Magnetic water treatment for scale prevention. Wat. Res., 35 (13), 3249-3259. https://doi. org/10.1016/S0043-1354(01)00010-0

Gheisar, M. M., \& Kim, I. H. (2018). Phytobiotics in poultry and swine nutrition - a review. Italian Journal of Animal Science, 17 (1), 92-99. https:// doi.org/10.1080/1828051X.2017.135 0120

Gholizadeh, M., Arabshahi, H., Saeidi, M. R., \& Mahdavi, B. (2008). The effect of magnetic water on growth and quality improvement of poultry. Middle-East Journal of Scientific Research, 3 (3), 140-144.

Grashorn, M. A. (2010). Use of phytobiotics in broiler nutrition - an alternative to infeed antibiotics. Journal of Animal and Feed Science, 19, 319-328. https:/ /doi.org/10.22358/jafs/66297/2010

Gumus, H., Oguz, M. N., Bugdayci, K. E., \& Oguz, F. K. (2018). Effects of sumac and turmeric as feed additives on performance, egg quality traits, and blood parameters of laying hens. Brazilian Journal of Animal Science, 
47, 1-7. http://dx.doi.org/10.1590/rbz 4720170114

Gurbuz, Y., \& Salih, Y. G. (2017). Influence of sumac (Rhus coriaria L.) and ginger (Zingiber officinale) on egg yolk fatty acid, cholesterol and blood parameters in laying hens. Journal of Animal Physiology and Animal Nutrition, 101 (6), 1316-1323. https:// doi.org/10.111 1/jpn.12652

Hazrati, S., Rezaeipour, V., \& Asadzadeh, S. (2019). Effects of phytogenic feed additives, probiotics and mannanoligosaccharides on performance, blood metabolites, meat quality, intestinal morphology, and microbial population of japanese quail. British Poultry Science, 61 (2), 132-139. https://doi.org/10.1080/00071668.201 9.1686122

Incharoen, T., \& Yamauchi, K. (2009). Production performance, egg quality and intestinal histology in laying hens fed dietary dried fermented ginger. International Journal of Poultry Science, 8 (11), 1078-1085. https://dx. doi.org/10.3923/ijps.2009.1078.1085

Jiang, L., Zhang, J., \& Li, D. (2015). Effects of permanent magnetic field on calcium carbonate scaling of circulating water. Desalination and Water Treatment, 53 (5), 1275-1285. https://doi.org/10.1080/19443994.201 3.850450

Kafi, A., Uddin, M. N., Uddin, M. J., Khan, M. M. H., \& Haque, M. E. (2017). Effect of dietary supplementation of turmeric (Curcuma Longa), ginger (Zingiber Officinale) and their combination as feed additives on feed intake, growth performance and economics of broiler. International Journal of Poultry Science, 16 (7), 257-265. http://www.dx.doi.org/10.3 923/ijps.2017.257.265

Kinati, C., Ameha, N., Girma, M., \& Nurfeta, A. (2021). Efective microorganisms, turmeric (Curcuma longa) as feed additives on production performance and sensory evaluation of eggs from white leghorn hens. Livestock Research for Rural Development, 33 (1).

Kosti, D., Dahiya, D. S., Dalal, R., Tewatia, B. S., \& Vijayalakshmy, K. (2020). Role of turmeric supplementation on production, physical and biochemical parameters in laying hens. World's Poultry Science Journal, 76 (3), 625637. https://doi.org/10.1080/004393 39.2020.1764460

Lee, J., Kim, D., Kim, Y., Jeong, S., Oh, S., Cho, S., \& Lee, K. (2020). Dietary encapsulated essential oils improve production performance of coccidiosisvaccine-challenged broiler chickens. Animals, 10 (3), 481. https://doi.org/ 10.3390/ani10030481

Mitre, K. (2018). The Effect of Magnetic Water on Feed Conversion Ratio, Body Weight Gain, Feed Intake and Livability of Male Broiler Chickens. Poultry Science Undergraduate Honors Theses Poultry Science, University of Arkansas, Fayetteville ScholarWorks@UARK.

Mousa, B. H., Awad, A. M., Alhamdani, H. A. A. A., Nafea, H. N., \& Alhamdani, A. A. Inclusion of garlic (Allium Sativum.) and turmeric (Curcuma longa L.) powder to laying hens' diets on egg quality traits, bacterial population and intestinal histomorphology. Annals of Tropical Medicine and Public Health, 22 (12), 231-240. http://doi.org/10.36295/AS RO.2019.221224

Natsir M. H., Sjofjan, O., Umam, K., Manab, A., \& Widodo, E. (2010). Effects of liquid and encapsulated lactic acid in broiler diets on performances, intestinal characteristics and intestinal microflora. J. Poult. Sci., 47 (3), 240243. https://doi.org/10.2141/jpsa.009099 Natsir, M. H., Hartutik, Sjofjan, O., \& Widodo, E. (2013). Effect of either powder or encapsulated form of garlic and phyllanthus niruri $l$. mixture on broiler performances, intestinal characteristics and intestinal 
microflora. Int. J. Poult. Sci., 12, 676680. https://dx.doi.org/10.3923/ijps. 2013.676.680

Pineda-Quiroga, C., Atxaerandio, R., Zubiria, I., Gonzalez-Pozuelo, I., Hurtado, A., Ruiz, R., \& GarciaRodriguez, A. (2017). Productive performance and cecal microbial counts of floor housed laying hens supplemented with dry whey powder alone or combined with pediococcus acidilactici in the late phase of production. Livestock Science, 195, 9-

12. https://doi.org/10.1016/j.livsci.20 16.11.007

Rahman, M. A., Ray, D., Redoy, M. R. A., \& Al-Mamun, M. (2021). Dose titration of herbs mixture powder supplementation on laying performance and egg quality in commercial layer chicken. Livestock Research for Rural Development, 33 (1).

Riasi, A., Kermanshahi, H., \& Mahdavi, A. H. (2012). Production performance, egg quality and some serum metabolites of older commercial laying hens fed different levels of turmeric rhizome (Curcuma longa) powder. Journal of Medicinal Plants Research, 6 (11), 2141-2145. http:// dx.doi.org/10.5897/JMPR11.1316

Roberts, J. R. (2004). Factors affecting egg internal quality and egg shell quality in laying hens. Journal of Poultry Science, 41, 161-177. https://doi.org/ 10.2141/jpsa.41.161

Saraswati, T. R., Manalu, W., Ekastuti, D. R., \& Kusumorini, N. (2013). The role of turmeric powder in lipid metabolism and its effect on quality of the first quail's egg. Journal of the Indonesian Tropical Animal Agriculture, 38 (2), 123-130. https:// doi.org/10.14710/jitaa.38.2.123-130

Sunder, J., Jeyakumar, S., Sujatha, T., \& A. Kundu. (2013). Effect of feeding of morical (Morinda citrifolia) based herbal supplement on production and egg quality in nicobari fowl. Academic Journals, 7 (40), 2999-3002. https:// doi.org/10.5897/JMPR12.1120

Wen, C., Gu, Y., Tao, Z., Cheng, Z., Wang, T., \& Zhou, Y. (2019). Effects of ginger extract on laying performance, egg quality, and antioxidant status of laying hens. Animals, 9 (11), 857. https://doi.org/10.3390/ani9110857

Wen, C., Gu, Y., Tao, Z., Cheng, Z., Wang, T., \& Zhou, Y. (2019). Effects of ginger extract on laying performance, egg quality, and antioxidant status of laying hens. Animals, 9 (11), 857. https://doi.org/10.3390/ani9110857

Y1ldırım, A., Şekeroğlu, A., Eleroğlu, H., Şen, M. I., \& Duman, M. (2013). Effects of korean ginseng (Panax ginseng C.A. Meyer) root extract on egg production performance and egg quality of laying hens. South African Journal of Animal Science, 43, 194207. http://dx.doi.org/10.4314/sajas. v43i2.10

Zhang, G. F., Yang, Z. B., Wang, Y., Yang, W. R., Jiang, S. Z., \& Gai, G. S. (2009). Effects of ginger root (Zingiber officinale) processed to different particle sizes on growth performance, antioxidant status, and serum metabolites of broiler chickens. Poultry Science, 88, 2159-2166. https: //doi.org/10.3382/ps.2009-00165

Zhao, X., Yang, Z. B., Yang, W. R., Wang, Y., Jiang, S. Z., \& Zhang, G. G. (2011). Effects of ginger root (Zingiber officinale) on laying performance and antioxidant status of laying hens and on dietary oxidation stability. Poultry Science, 90, 1720-1727. https://doi. org/10.3382/ps.2010-01280 